\title{
Offshore phytoplankton biomass increase and its oceanographic causes in the South China Sea
}

\author{
DanLing Tang ${ }^{1,2,3, *}$, Hiroshi Kawamura ${ }^{3}$, Tran Van Dien ${ }^{4}$, MingAn Lee $^{5}$ \\ ${ }^{1}$ LED, South China Sea Institute of Oceanology, Chinese Academy of Sciences, 164 West Xingang Road, Guangzhou 510301, \\ China \\ ${ }^{2}$ Department of Environmental Science and Engineering, Fudan University, Shanghai 200433, China \\ ${ }^{3}$ Center for Atmospheric and Oceanic Studies, Graduate School of Science, Tohoku University, Sendai 980-8578, Japan \\ ${ }^{4}$ Haiphong Institute of Oceanography, 246 Da Nang Street, Haiphong City 84-31, Vietnam \\ ${ }^{5}$ Department of Environmental Biology and Fisheries Science, National Taiwan Ocean University, 2 Pei-Ning Road, \\ Keelung 20224, Taiwan
}

\begin{abstract}
High phytoplankton biomass often occurs in plumes near river mouths or in eutrophic coastal waters for short time periods. However, we observed an increased phytoplankton biomass in a narrow jet-shaped protrusion into the western South China Sea (SCS) using satellite chlorophyll a (chl a) data from the Sea-viewing Wide Field-of-view Sensor (SeaWiFS) and concurrent ship measurements in 1999. In June, regional phytoplankton biomass appeared as a large jet shape extending from the coastal waters of Vietnam eastward towards the SCS, about $200 \mathrm{~km}$ northeast of the mouth of the Mekong River; this feature intensified in the form of a large jet or gyre from July to September, decayed in October, and disappeared entirely in November. The gyre was about $400 \mathrm{~km}$ in diameter with chl a concentrations from 0.5 to $2 \mathrm{mg} \mathrm{m}^{-3}$. Data on sea surface temperature (SST), winds, and sea surface height anomalies indicated a strong offshore upwelling during a period of strong southwesterly winds alongshore. The upwelling coincided with the regional increase in phytoplankton biomass in terms of shape, timing, and location. We observed this phenomenon during every southwesterly monsoon season from 1997 to 2002 using chl a images from 3 satellite ocean color sensors - SeaWiFS, Ocean Color and Temperature Scanner (OCTS), and Ocean Color Imager (OCI) — and it appeared to be related to the cross-shelf upwelling that delivers nutrients to surface waters. The phytoplankton then flowed with a large anticyclonic gyre into the western SCS.
\end{abstract}

KEY WORDS: Phytoplankton · Chl a concentration · Upwelling · Monsoon · Satellite observation · SeaWiFS · South China Sea

Resale or republication not permitted without written consent of the publisher

\section{INTRODUCTION}

The South China Sea (SCS) is located in the western Pacific Ocean (see Fig. 1A). Most studies on biological processes in the SCS have concentrated on small areas, bays, lagoons, or coastal waters (An \& Du 2000, Penjan et al. 2000, Suchint \& Puntip 2000, Tang et al. $2003 a, b, c)$. Due to the large area, it is difficult to carry out biological surveys for the whole SCS; thus, we have limited knowledge of its marine ecology. Satelliteremote sensing data on chl $a$ with the advantages of spatial and temporal coverage have been lacking for this region.
Chl a concentrations and phytoplankton biomass are important to the economy of the ocean with respect to trophodynamics, primary production and fisheries, as well as to global biogeochemical cycles. High phytoplankton biomass often occurs as plumes in eutrophic waters near river mouths or along coasts (Tang et al. 1998, 1999, 2002a,b) because nutrients are most important factors controlling phytoplankton growth. However, preliminary observations in this study - from, for example, analysis of Ocean Color and Temperature Scanner (OCTS) chl a data for Asian waters (Tang \& Kawamura 2002) and Sea-viewing Wide Field-of-view Sensor (SeaWiFS) ocean color images — revealed phyto- 

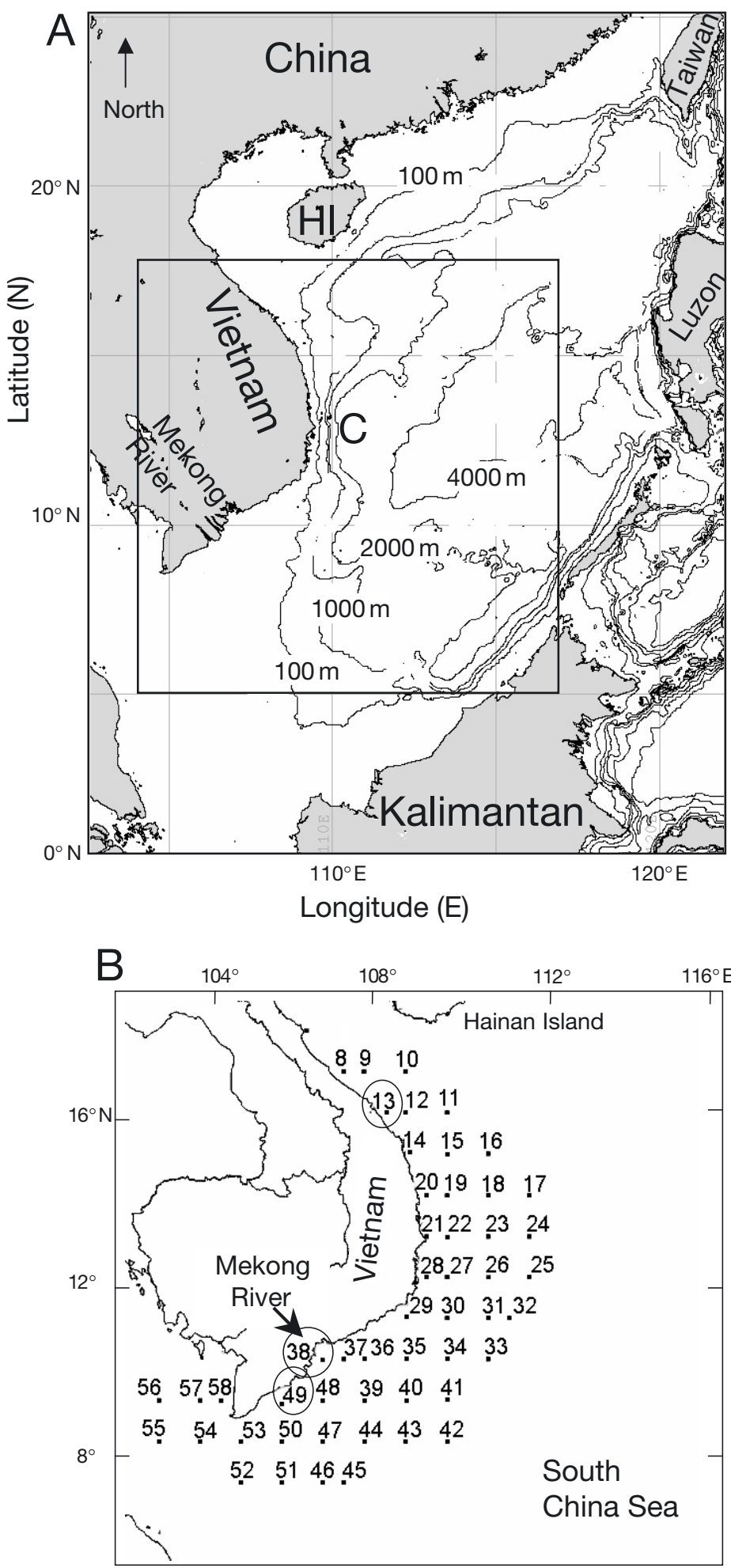

Fig. 1. (A) The geography and bathymetry of the study area (box) in the South China Sea. ' $\mathrm{C}$ ' indicates a narrow slope along the coast. HI: Hainan Island. (B) Locations of the 51 sampling stations in the western South China Sea. High chl $a$ concentrations $\left(>0.5 \mathrm{mg} \mathrm{m}^{-3}\right)$ were observed during the April 30 to May 29, 1999 survey at circled stations plankton plumes directed offshore from the Vietnamese coast into the SCS and encouraged us to examine more historical data and other oceanographic data. Why was phytoplankton biomass increased offshore toward the open sea? How long did this high phytoplankton biomass feature exist and how often did it occur? What was the source of nutrients that supported phytoplankton growth? In the present study, we analyzed a combination of satellite data on $\mathrm{chl} a$, sea surface temperature (SST), winds, and sea-level height to understand oceanographic and biological processes related to this phenomenon. We also compared SeaWiFS chl a with survey data for the first time in this region. These new observations may help us to develop a better understanding of the transfer of nutrients and biomass from coastal waters to the open sea, and from deep water to surface water; they may also help us to understand better the biological and oceanographic process in the SCS, e.g. the effects of windforcing on marine biology in this region.

\section{MATERIALS AND METHODS}

Study area and survey measurements. The SCS lies between the equator and the Tropic of Cancer, and its bottom topography is characterized by a basin with a maximum depth of $5000 \mathrm{~m}$ at the center, wide continental shelves in the north and south, and steep slopes on the east and west sides. Our study area (Fig. 1) was the western SCS, with a very narrow, steep bathymetry and depths ranging from 100 to $4000 \mathrm{~m}$ along the eastern Vietnamese coast. The Mekong River (Fig. 1) is the major river discharging into the study area. This region experiences reversed tropical monsoons. The southwesterly monsoon first appears in May, and it expands to cover the entire basin of the SCS during July and August; the northeasterly monsoon begins in late September (Shaw \& Chao 1994). The monsoon winds play an important role in hydrological features and the general circulation in the study region.

Chl a concentrations were measured at 51 stations in the western SCS (Fig. 1B) by a Southeast Asian Fisheries Development Center (SEAFDEC) cruise conducted from April 30 to May 29, 1999. Water samples ( 2 to $5 \mathrm{l}$ ) were collected for surface ( $2 \mathrm{~m}$ ) distributions and vertical profiles. Sampling depths were monitored with an ICTD (Integrated Conductivity, Temperature, and Depth Sensor) at each station. Water samples were pre-filtered with a plankton net of $300 \mu \mathrm{m}$ mesh size and vacuum filtered through GF/F filters under $25 \mathrm{~cm}$ $\mathrm{Hg}$ in the dark. The extracted samples were analyzed on a Thermo-separation HPLC system (a binary gradient pump, auto-sampler, UV detector, and degasser) 
(Suchint \& Puntip 2000). There were 58 stations on the cruise. In the present study, we used data from 51 stations (Stns 8 to 58) within the study area.

Satellite-derived chl a concentrations. SeaWiFS: SeaWiFS-derived chl a images of $1 \mathrm{~km} \times 1 \mathrm{~km}$ spatial resolution were processed by the Asian I-Lac Project (Tang \& Kawamura 2002) with the SeaWiFS Data Analysis System (SeaDAS) using Ocean Color 4-band algorithm $(\mathrm{OC} 4,4)$ (O'Reilly et al. 1998). To investigate the spatial distribution of chl $a$, we first processed images at $1 \mathrm{~km} \times 1 \mathrm{~km}$ spatial resolution, and then made monthly averaged chl a images at $4 \mathrm{~km} \times 4 \mathrm{~km}$ spatial resolution for 1998 to 2001. The number of image scenes per month for 1999 is given in Table 1.

To compare SeaWiFS data with survey measurements, we selected 51 stations at the same locations as the SEAFDEC survey (Fig. 1B) to sample chl a values from 1 monthly averaged SeaWiFS image for May 1999. Mean chl a was calculated for every $5 \times 5$ pixels $(20 \mathrm{~km} \times 20 \mathrm{~km})$. We used a monthly average because a single scene does not have sufficient data coverage, and the survey was done during the entire month of May.

OCTS: OCTS-derived chl a images with $1 \mathrm{~km} \times 1 \mathrm{~km}$ resolution were processed with SeaDAS (MSL 1) (Baith et al. 2001), using the in-water algorithm developed by Kishino et al. (1998). We processed 1 monthly averaged OCTS chl $a$ image at $4 \mathrm{~km} \times 4 \mathrm{~km}$ spatial resolution for June 1997.

Ocean Color Imager (OCI): OCI is an all-refractive spectral radiometer that has 6 spectral bands spanning from visible to near infrared. It was launched in December 1999 onboard ROCSAT-1, a low-earth orbiter, by Taiwan. OCI data were collected and provided by the Science Data Distribution Center of Ocean Color Imager (http://www.oci.ntou.edu.tw/) in the National Taiwan Ocean University in Keelung, Taiwan (Li et al. 1999).

Sea surface temperature (SST) and other oceangraphic data. Advanced very high resolution radiometer (AVHRR) SST: NOAA satellites provide SST measurements from AVHRR instruments. SST images with

Table 1. Number of SeaWiFS scenes for processing monthly averaged chl a images in 1999 (Fig. 2)

\begin{tabular}{|cc|}
\hline Month (1999) & Number of scenes \\
\hline March & 24 \\
April & 23 \\
May & 29 \\
June & 26 \\
July & 26 \\
August & 30 \\
September & 25 \\
October & 23 \\
November & 29 \\
\hline
\end{tabular}

$1.1 \mathrm{~km} \times 1.1 \mathrm{~km}$ spatial resolution at nadir were obtained from the receiving station in the National Taiwan Ocean University (Hsu et al. 2000). Cloud-free images were processed to obtain the multi-channel SST data (Emery et al. 1986, Kubota 1994). Monthly SST data were formed by arithmetically averaging all available scenes in each month on a pixel-by-pixel basis (excluding missing data and clouds).

Sea surface winds: We analyzed sea surface wind conditions to describe air-sea interactions. The microwave scatterometer SeaWinds QuikScat was launched on the QuikBird satellite in June 1999. QuikScat is essentially a radar device that transmits radar pulses to the Earth's surface and measures the power that is scattered back to the instrument. Wind speed and direction over the ocean surface were retrieved from QuikScat measurements of backscattered power (Wentz et al. 2001). Monthly averaged QuikScat wind vector images were produced by Remote Sensing Systems and sponsored by the NASA Ocean Vector Winds Science Team (http://www.ssmi.com/qscat/qscat_ description.html). July 1999 was the earliest month that we were able to obtain wind data for the region.

Sea surface height: To compare the surface height anomalies between summer and winter seasons, we processed 10 d mean sea surface height anomaly (SSHA) images derived from TOPEX/POSEIDON altimeter data (Andersen 1995). Data were obtained for the periods February 19 to March 1, and August 16 to 26, 1999.

\section{RESULTS}

\section{Survey of chl a concentrations in the western SCS}

The depths of 51 stations (Fig. 1B) ranged from $20 \mathrm{~m}$ (Stn 49) to $4117 \mathrm{~m}$ (Stn 25) (Fig. 2A). Stations near the coast ranged from 20 to $100 \mathrm{~m}$ deep, and stations in the open sea were deeper than $500 \mathrm{~m}$. Surface chl a concentrations were generally low $\left(<0.2 \mathrm{mg} \mathrm{m}^{-3}\right)$ in the open sea, whereas high chl a concentrations (>0.5 mg $\mathrm{m}^{-3}$ ) were observed at several stations near the river mouth or in shallow waters, including Stns 13, 38, 49 and 54 (Fig. 2C; circled in Fig. 1B). The chl a maximum ranged from $20 \mathrm{~m}$ to $90 \mathrm{~m}$ (Fig. 2B); chl a concentrations were higher in this layer than at the surface.

Satellite derived chl a concentrations were generally higher than survey measurements, but the 2 data sets showed general agreement over the study area. Regression line $y=1.6468 x-0.0914$ (Fig. 2D) shows the comparison between survey data and satellite data. One data point far from this line (Fig. 2D, Stn 38) corresponds to a location at the mouth of the Mekong River at a depth of $21 \mathrm{~m}$, where the river discharge may have affected the satellite-derived chl a value. 
A. Depth of bottom

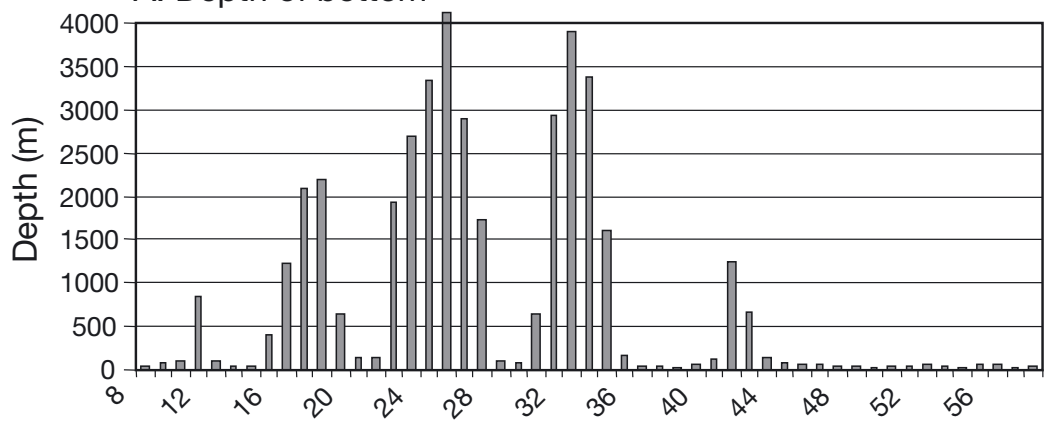

B. Depth of chl a maximum layer

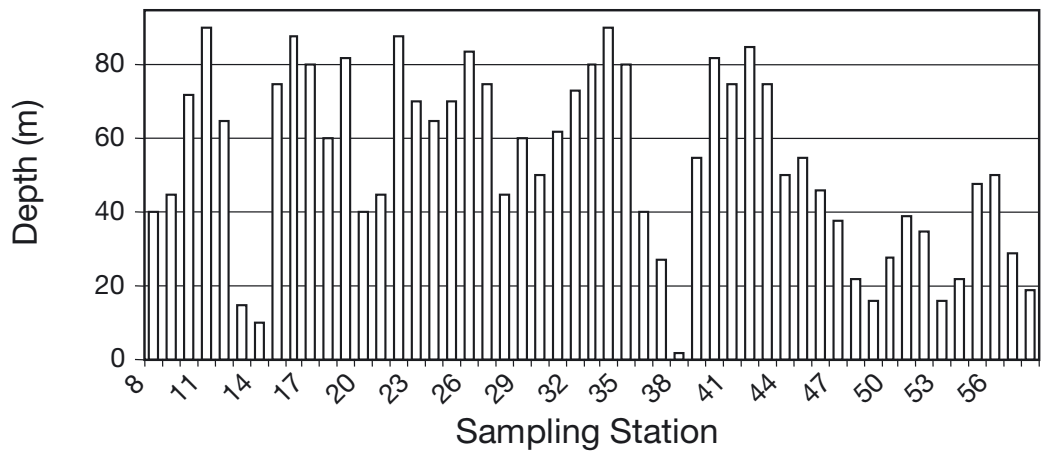

Regional increase of phytoplankton biomass

Monthly averaged SeaWiFS chl a concentrations from April to November 1999 revealed a large region of high phytoplankton biomass in the western SCS from July to September (Fig. 3). In April (Fig. 3A), chl a concentrations were generally low $\left(0.1 \mathrm{mg} \mathrm{m}^{-3}\right)$ and uniformly distributed in the western SCS. In the May image, a phytoplankton plume appeared in the water of the Mekong River mouth (a in Fig. 3B), in agreement with the May survey (Fig. 2C). High chl a concentrations $\left(>2 \mathrm{mg} \mathrm{m}^{-3}\right)$ appeared at Stn 38, located near the river mouth (MR) (white circle in Fig. 3B). In June, we observed a region of increased chl $a$ in the western SCS (b in Fig. 3C). This high phytoplankton biomass was about $200 \mathrm{~km}$ northeast of the Mekong River mouth and directed offshore from the Vietnamese coast. It agreed with previous observations of OCTS images obtained in June 1997 (Tang \& Kawamura 2002). The phytoplankton plume near the river mouth was still present in this month (a in Fig. 3C). In July (Fig. 3D), high chl a concentration extended as a jet about $500 \mathrm{~km}$ long and $150 \mathrm{~km}$ wide into the open sea (b in Fig. 3D). The jet had a higher chl a concentration $\left(2 \mathrm{mg} \mathrm{m}^{-3}\right)$ on the coastal side and a lower chl a concentration $(0.5 \mathrm{mg}$ $\mathrm{m}^{-3}$ ) on the seaward side. In August, the region of high phytoplankton biomass extended eastward and turned southwest, appearing as a large gyre $400 \mathrm{~km}$ in diameter (b in Fig. 3E) in the SCS (8 to $13^{\circ} \mathrm{N}, 109$ to $115^{\circ} \mathrm{E}$ ). It persisted as a long jet in September (b in Fig. 3F) -in agreement with our previous observations in September 1998 (Fig. 4A) - decayed in October (b in Fig. 3G) and disappeared entirely in November (Fig. 3H). However, the phytoplankton plume in the Mekong River mouth could still be observed (a in Fig. 3H).

\section{Annual reoccurrence of high phytoplankton biomass}

We found that the regional increase in phytoplankton biomass protruded offshore in southwesterly monsoon seasons from 1997 to 2002 (Fig. 5). A monthly OCTS $\mathrm{chl}$ a image first revealed this as a plume extending $200 \mathrm{~km}$ into the open sea in June 1997 (b in Fig. 5A). Subsequently, 3 monthly SeaWiFS images showed the high phytoplankton biomass (b in Fig. 5B-D) from 1998 to 2000. The feature shifted north in August 1998 (b in Fig. 5B) and was also observed in 2 single-scene

Fig. 2. Chl a concentrations obtained at 51 stations (Fig. 1B) in May 1999. (A) Depths of stations, (B) depths of chl a maximum layer at stations, (C) chl a concentrations at stations from survey and SeaWiFS satellite in May 1999, and (D) comparison between SeaWiFS chl $a$ and survey measurements in May 1999 

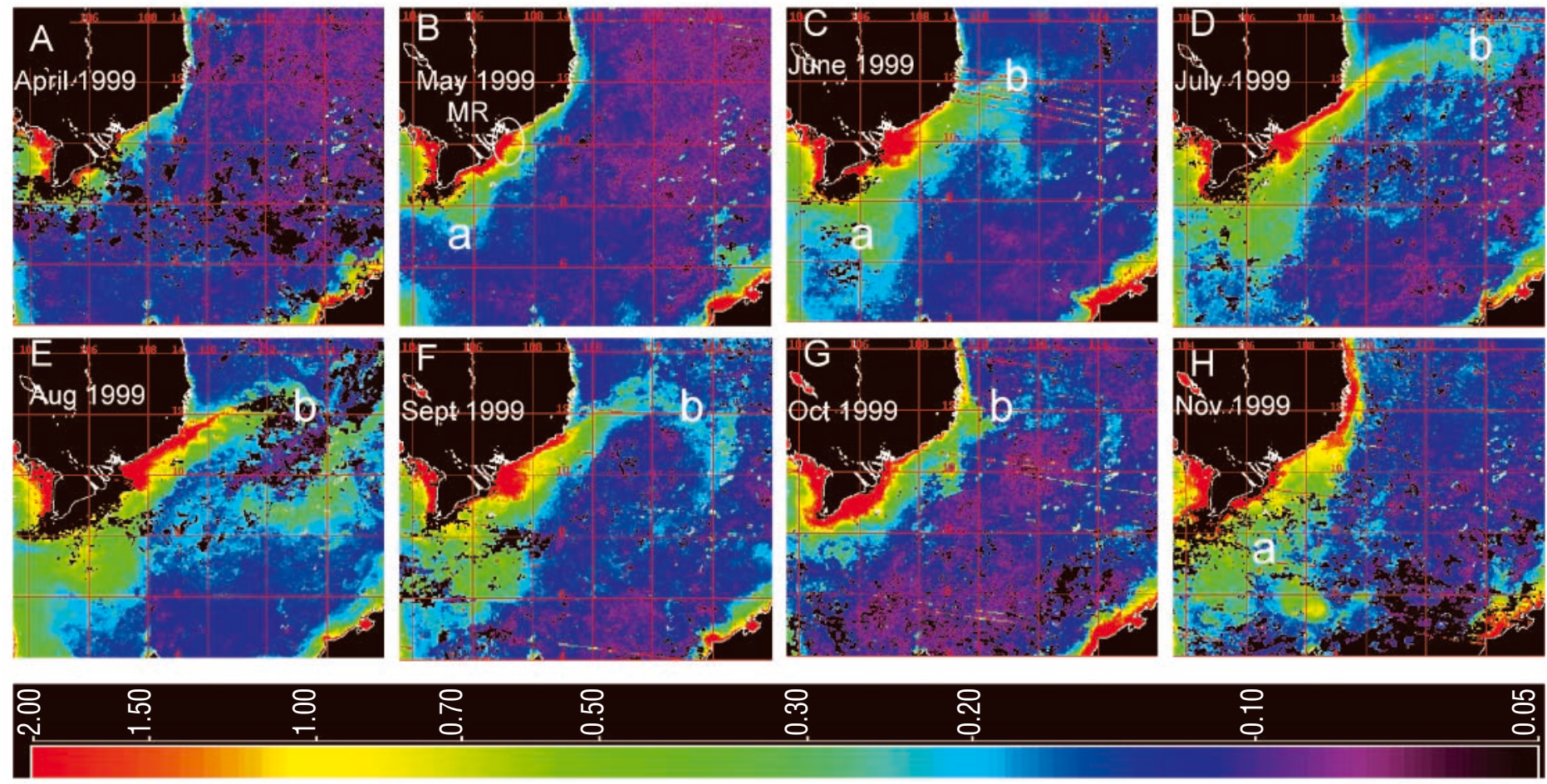

\section{SeaWiFS chl a concentration $\left(\mathrm{mg} \mathrm{m}^{-3}\right)$}

Fig. 3. Monthly SeaWiFS derived chl a images from (A) April to (H) November 1999, showing a regional increase in phytoplankton biomass (b) offshore in the western SCS and a phytoplankton plume (a) near the Mekong River mouth. See also Fig. 4. MR: Mekong River

OCI images obtained in July 2001 and 2002 (b in Fig. 5E,F). It appeared as a large gyre on July 17, 2002 (Fig. 4B), extending about $500 \mathrm{~km}$ into the western SCS. The phytoplankton plume in the Mekong River mouth can also be observed (a in Fig. 5).

\section{Wind, temperature, and sea surface height}

\section{Wind}

Monthly averaged wind images obtained from July to November 1999 (Fig. 6) indicated very strong southwesterly winds parallel to the Vietnamese coastline in July (circle in Fig. 6A). The speed of alongshore winds reached $13 \mathrm{~m} \mathrm{~s}^{-1}$. The southwesterly winds continued in August (Fig. 6B) and decayed in September (Fig. 6C). In late autumn, the wind direction changed. Northeasterly winds occurred in October (Fig. 6D) and strengthened in November (Fig. 6E).

\section{SST}

Monthly averaged SST images (Fig. 7) reveal the seasonality of water temperature in the western SCS. In February 1999 (Fig. 7A), SST was relatively low compared to other months $\left(25^{\circ} \mathrm{C}\right)$ and uniformly distributed.
However, in July 1999 (Fig. 7B), SST was high $\left(28^{\circ} \mathrm{C}\right)$ in most places, and we found a narrow band of low SST along the Vietnamese coast (arrow in Fig. 7B). The cold water region started at the coast and extended northeast toward the open sea. It coincided with the offshore increase in phytoplankton biomass (Fig. 3C-F, Fig. 4, Fig. 5) in terms of timing, location and shape.

\section{Sea surface height anomaly}

Sea surface height anomaly images (Fig. 8) showed a seasonal reversal of southwesterly and northwesterly monsoons in the SCS. A filament of low height ( $\mathrm{J}$ in Fig. 8B) appeared offshore in the western SCS in August, coinciding with increased phytoplankton biomass (Figs. $3 \&$ 5) and low SST (Fig. 7B) in terms of shape, location, and season. This feature was not present in February (Fig. 8A).

\section{DISCUSSION}

\section{Satellite observations of $\mathrm{chl} a$ in the western SCS}

Our results show that SeaWiFS chl a values matched survey measurements in most area in the western SCS, 

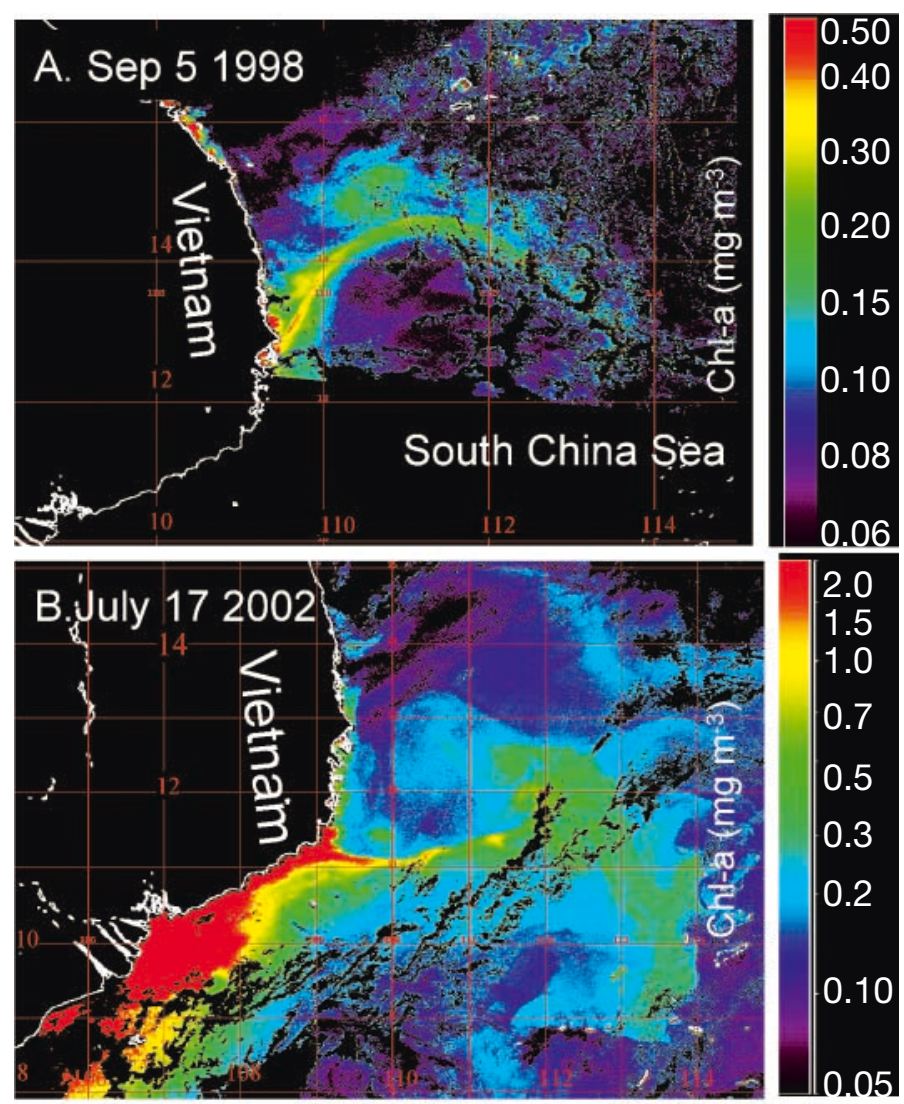

Fig. 4. SeaWiFS derived chl a images showing a region of high phytoplankton concentration as (A) a jet and (B) a gyre from the Vietnamese coast toward the western SCS. Land, clouds and missing data are marked black, and coastlines are shown in white

including coastal waters (Fig. 2C), but SeaWiFS chl a values were higher than survey measurements near the Mekong River mouth (Fig. 2C,D), i.e. Stns 38 and 49 (Fig. 1B). Satellite-derived data may overestimate chl a in Case II (coastal) waters due to the influence of suspended material (SM) and colored dissolved organic matter (CDOM) (Sathyendranath et al. 2000). In our study area (the open sea), the influences of SM and CDOM may be relatively limited, except near the river mouth, e.g. Stn 38. These results suggest that satellite chl a data could help us to observe spatial distribution of $\mathrm{chl} a$ in the offshore region over the western SCS.

In the present study, OCI data were studied for the first time for the western SCS, and showed consistent results with OCTS and SeaWiFS images. However, in waters adjacent to Taiwan in the northern SCS, OCI chl a concentrations are generally higher than SeaWiFS chl a (Li et al. 1999). Our results also indicate that single-image scenes may show more details of spatial distribution (Fig. 4), and monthly averaged images capture the temporal trends (Figs. 3 \& 5).

\section{Observations of high phytoplankton biomass}

Our results revealed a large regional increase in phytoplankton biomass during the southwesterly monsoon. This phenomenon may be summarized as (1) starting in western coastal waters and extending as a large jet directed into the western SCS, (2) intensifying as a large gyre in the western SCS, (3) persisting for 4 mo from late June to October, (4) and occurring only during the southwesterly monsoon each year.

This large region of high phytoplankton biomass in the western SCS has not been reported before, possibly because (1) previous surveys (e.g. SEAFDEC) were not conducted during the southwesterly monsoon, (2) survey data were too sparse in spatial and temporal coverage to identify this regional phenomenon, and (3) multi-year satellite studies of ocean color over the entire area of the SCS were previously unavailable.

We do not know the nutrient source that supports high phytoplankton biomass in the open sea for a period of several months. Although the specific conditions that trigger a regional increase in phytoplankton biomass are difficult to specify, we can identify possible causes from our study.

\section{Mechanisms of the high phytoplankton biomass}

\section{Upwelling in the southwesterly monsoon season}

Nutrients are of highest importance in supporting phytoplankton growth in the western SCS, where solar radiation, light penetration, and temperature are not limiting factors (An \& Du 2000, Tang et al. 2003b,c). The Mekong River is the major freshwater and nutrient source in this area, and river-borne nutrients may support initiation of phytoplankton plumes near the mouth (a in Figs. 3 \& 5). In coastal water, chl a concentrations were higher at depth than at the surface, in agreement with observations by An \& Du (2000). Maximum chl $a$ values were found at 20 to $90 \mathrm{~m}$ (Fig. 2B).

How did the region of high biomass occur $200 \mathrm{~km}$ from the river mouth and extend offshore, and how was it maintained for $4 \mathrm{mo}$ ? The continental slope slopes very steeply to a depth of $2000 \mathrm{~m}$ in the western SCS (C in Fig. 1A). When strong southwesterly monsoon winds parallel the coastline (Fig. 6A) in late June, offshore Ekman transport induces a strong upwelling (Fig. 7B). Altimeter images from TOPEX/POS (Fig. 8B), with SST images from AVHRR (Fig. 7B), indicate that a strong offshore current extends from the coast of Vietnam as a cold-water jet. This upwelling may deliver nutrients from bottom waters to the surface and from coastal waters to the open sea, inducing an increase in phytoplankton biomass. The upwelled 
June 1997 OCTS

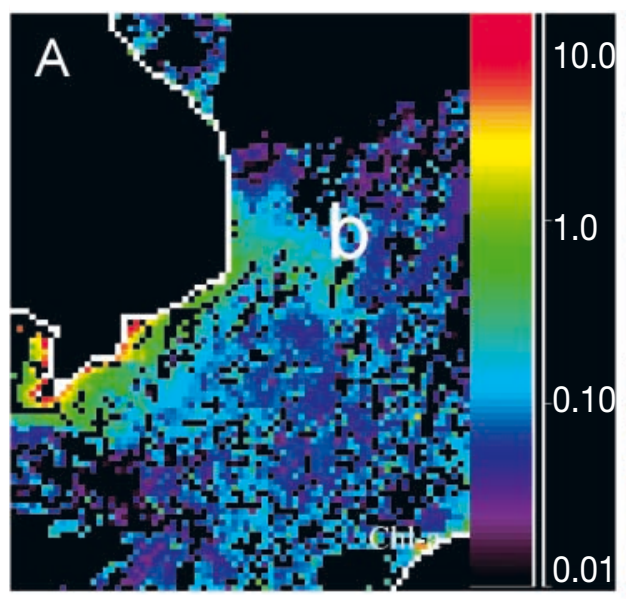

Sep 2000 SeaWiFS

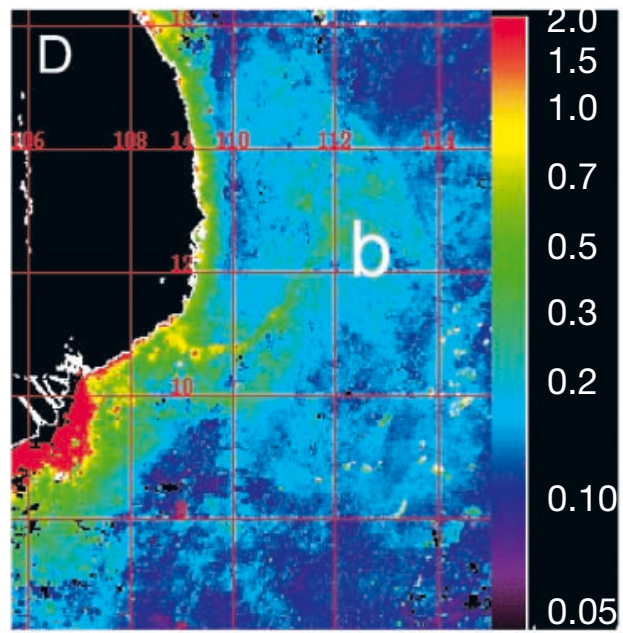

Aug 1998 SeaWiFS

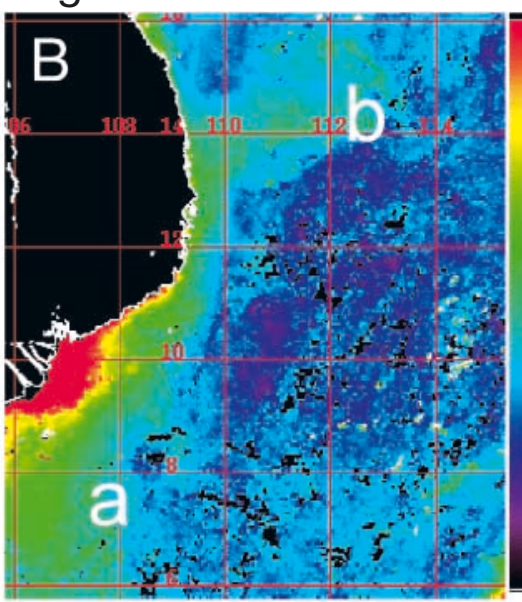

July $92001 \mathrm{OCl}$

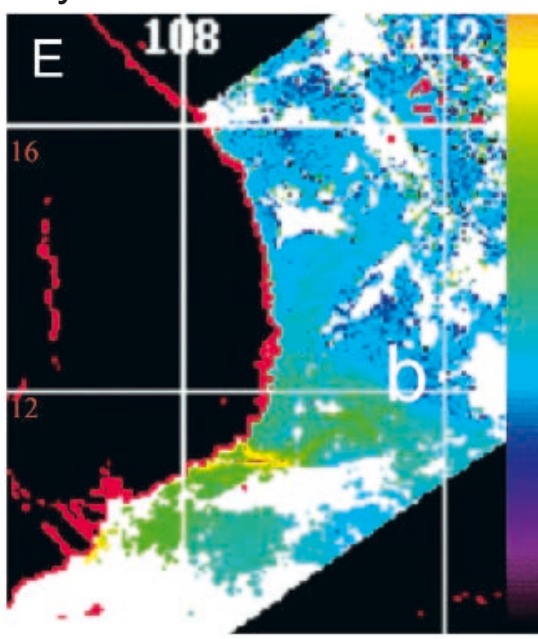

Sep 1999 SeaWiFS

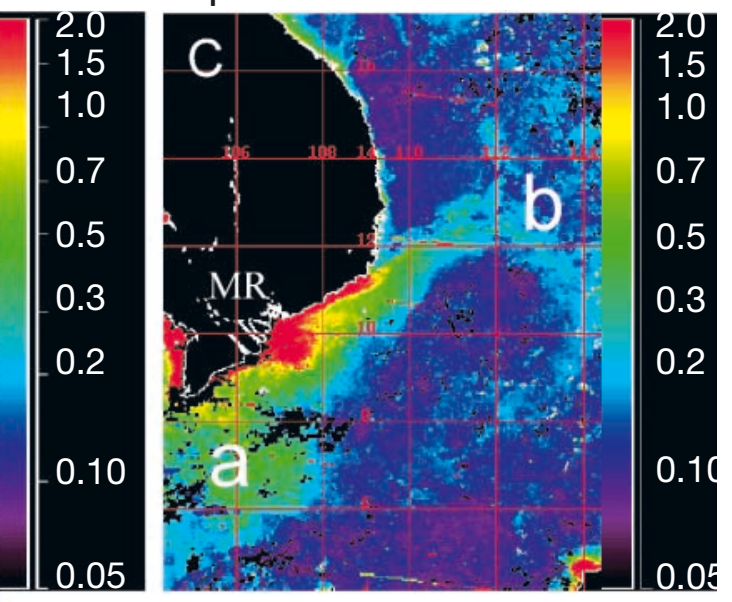

July 262002
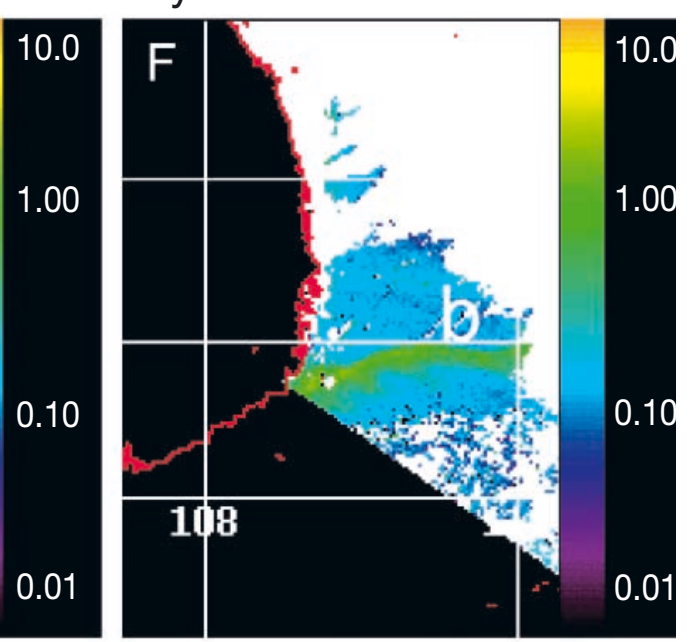

Fig. 5. Satellite derived chl a images for the western SCS showing a regional increased phytoplankton biomass protruding jet-shaped or gyreshaped in the southwesterly monsoon season during (A) 1997 to (F) 2002. See also Figs. 3 \& 4

July 1999

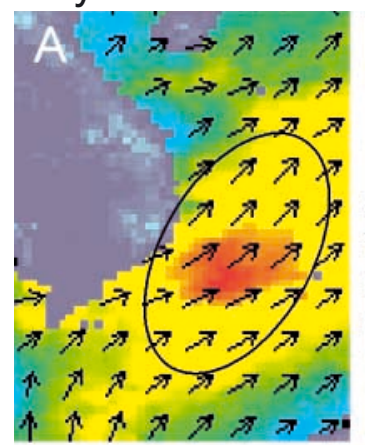

Aug 1999

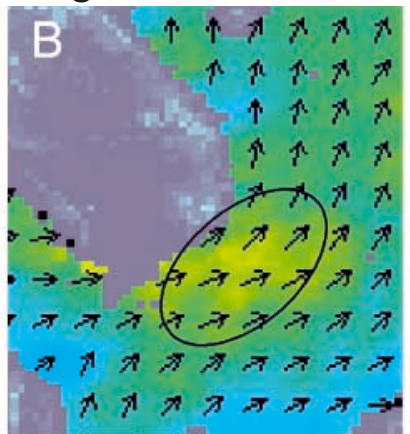

Sep 1999

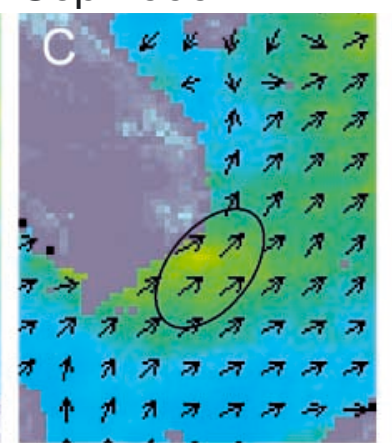

Oct 1999

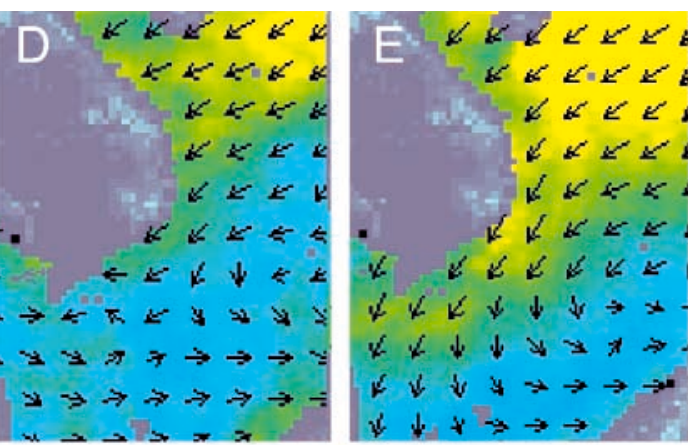

Nov 1999

$\downarrow \downarrow \forall \rightarrow \rightarrow+$

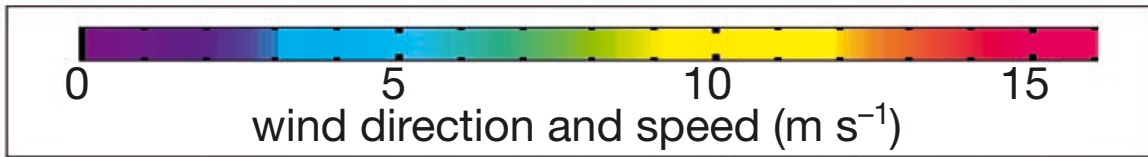

Fig. 6. Monthly averaged wind images obtained from June to November 1999. Land regions are colored gray. Small arrows indicate wind direction. Black ovals in A-C show strong southwesterly winds parallel to the coastline 


\section{A. Feb 1999}

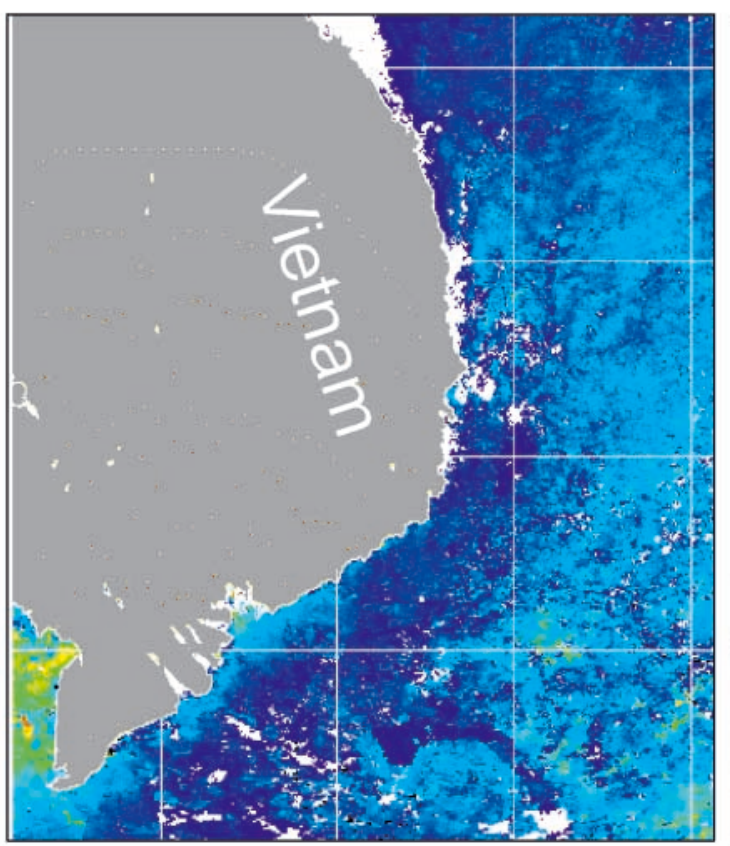

\section{B. July 1999}

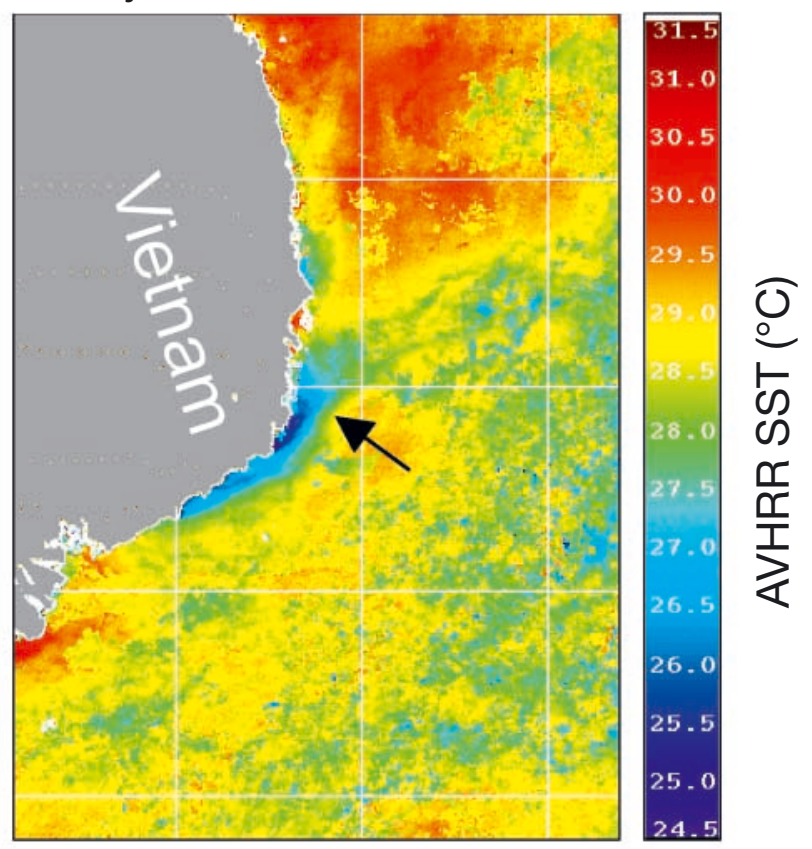

Fig. 7. Images of monthly averaged sea surface temperature (SST) for (A) winter and (B) summer. Land regions are colored gray, and coastlines are shown in white. Arrow indicates cold water upwelling from the coast toward the open ocean

water may also bring subsurface phytoplankton to the surface.

Regional upwelling has been observed in previous studies (Ho et al. 2000, Kuo et al. 2000) as occurring continuously during the southwesterly monsoon and supporting high phytoplankton biomass for 4 mo. Similar upwelling phenomena supporting high phytoplankton biomass have been observed in the Taiwan Strait (Tang et al. 2002b, 2003a) and the Luzon Strait (Tang et al. 1999) in the northeastern SCS. However,

\section{A. Feb 19-Mar 1, 1999}

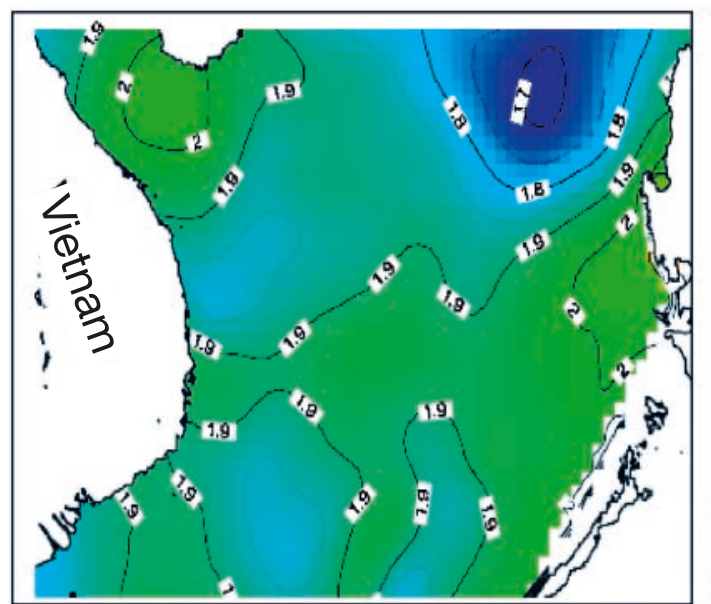

\section{B. Aug 16-26, 1999}

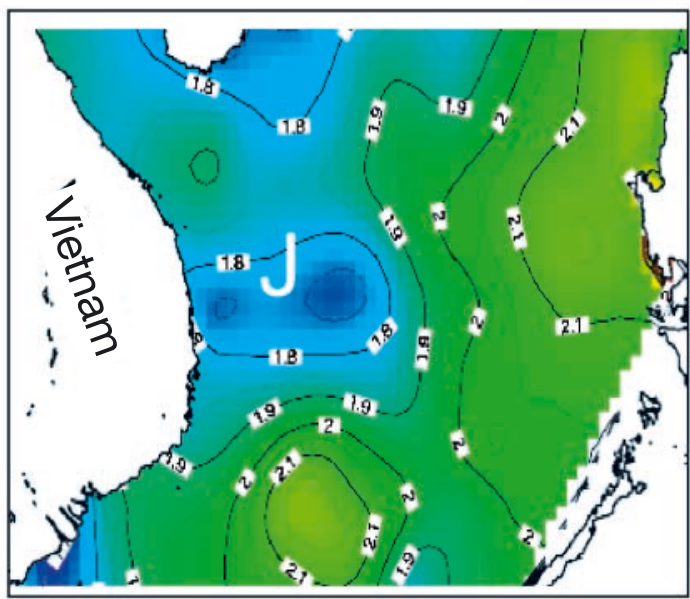

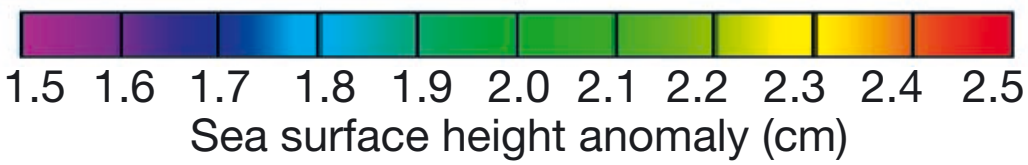

Fig. 8. Images of $10 \mathrm{~d}$ mean sea surface height anomaly (SSHA) in the western SCS for (A) winter and (B) summer in 1999. J: relatively low water filament 
our study presents the first observation of the extension of high phytoplankton water offshore into the western SCS.

\section{Ocean circulation and currents in the SCS}

Monsoon winds strongly drive circulation in the SCS (Wyrtki 1961). A large anticyclonic circulation (ac in Fig. 9A) appears during the southwesterly monsoon, and a cyclonic circulation (c in Fig. 9B) occurs during the northeasterly monsoon in the western SCS (Ho et al. 2000, Hu et al. 2000, Fang et al. 2002). In summer, there is an eastward offshore jet called the Summer Southeast Vietnam Offshore Current (Fang et al. 2002). Circulation and currents may have direct impacts on the distribution of phytoplankton biomass.

During the southwesterly monsoon, high phytoplankton biomass appeared as a large gyre, coinciding with anticyclonic circulation and the offshore current in location, shape, and season. This suggests that high phytoplankton biomass, after initiation by river discharge and offshore-directed upwelling, might subsequently flow with the current eastward to the open sea (b in Fig. 3E). This circulation might also deliver nutrients and phytoplankton from the Mekong River mouth northeastward, merging with the high offshore phytoplankton biomass.

During the monsoon transition seasons (Fig. 6C,D), upwelling and anticyclonic circulation weakened, and phytoplankton biomass decayed (Fig. 3G) due to nutrient exhaustion. When the northeasterly monsoon began (Fig. 6E), upwelling stopped (Fig. 7A), a cyclonic eddy occurred (Fig. 9B), and the regional increase in phytoplankton biomass disappeared (Fig. 3H).

\section{A. Southwesterly Monsoon}

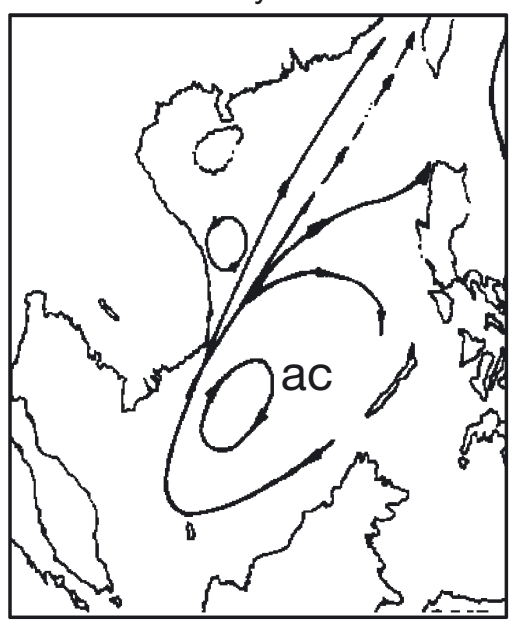

\section{B. Northwesterly Monsoon}

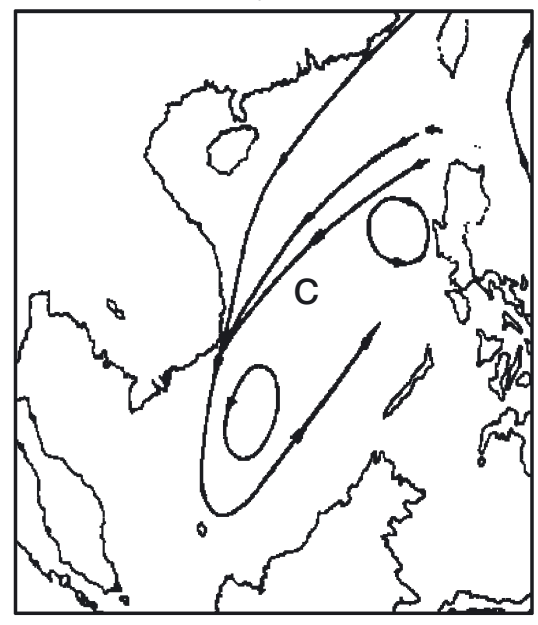

Fig. 9. Upper-layer mean circulation patterns in the SCS (after Hu et al. 2000) (A) in the southwesterly monsoon season and (B) in the northeasterly monsoon season. ac: anticyclonic eddy, c: cyclonic eddy
The high phytoplankton biomass shifted location to the north or south in some cases (Fig. 5B,E), possibly because of a shift in the upwelling and the offshore current. The upwelling center shifted from north to south in 1997 due to changes in wind direction and the current center (Kuo et al. 2000). The advection of coastal water would be indicated by salinity. More investigations on the water column are needed in future studies to understand these observations and mechanisms.

\section{Conclusions}

The present study revealed a large regional increase in phytoplankton biomass in the western SCS. This advective feature started in late June, matured from July to September, decayed in October, and disappeared in November. Our results showed this phenomenon to be remarkably consistent from year to year.

Fig. 10 shows a conceptual model of the mechanisms that match our observations. Nutrients from the Mekong River initiate the phytoplankton plume in the river mouth. When strong southwesterly winds parallel the coastline, strong offshore Ekman transport and upwelling occur that induce and support phytoplankton growth in a jet in the western SCS. Phytoplankton biomass then flows with a large anticyclonic circulation and offshore current into the western SCS, decays due to nutrient, and subsequently disappears exhaustion when the southeasterly monsoon ends and upwelling and anticyclonic circulation weaken.

Our results suggest that nutrients and phytoplankton biomass could move from coastal waters to the open sea, and from deep water to the surface. They also suggest a strong offshore-directed current in the western SCS during the southwesterly monsoon.

This study demonstrates the usefulness of satellite chl a for ocean current studies. SeaWiFS chl a showed good agreement with surveys in this region except in the river mouth. Single images may show more detail than monthly averaged images that display large-scale spatial and temporal trends. The combination of satellite data and concurrent survey measurements has led us to a better understanding of biological and oceanic processes, offering improvement upon the fragmentary observations obtained in previous biological and oceanographic surveys. 


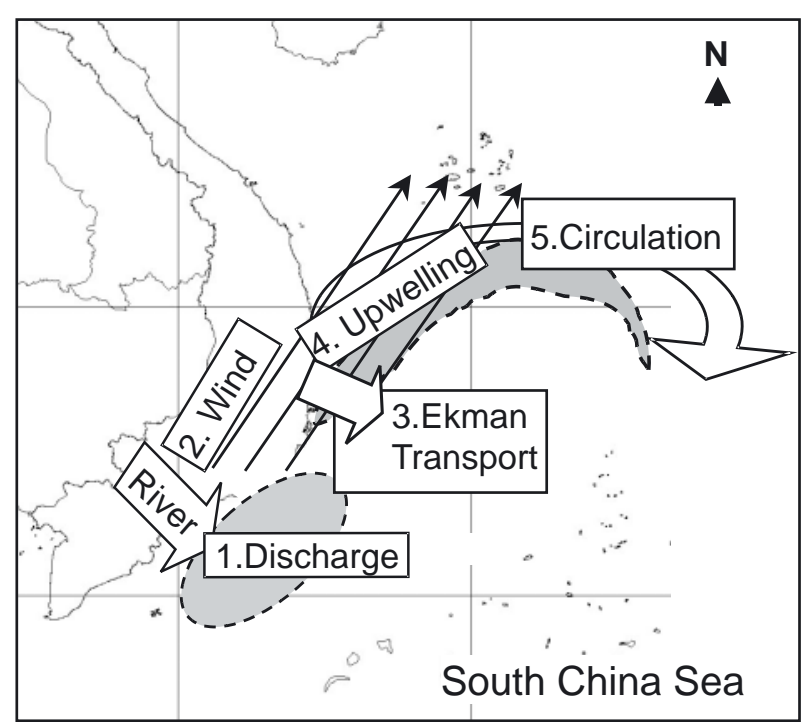

Fig. 10. Schematic diagram representing the mechanism of an offshore increased phytoplankton biomass (gray) in the South China Sea (SCS). River-discharged nutrients initiate a phytoplankton plume near the Mekong River mouth (1). Strong southwesterly winds parallel to the coastline (2), strong offshore Ekman transport (3) and upwelling (4) induce and support phytoplankton growth. The phytoplankton biomass flows with a large anyticyclonic circulation and offshore current into the SCS (5)

Acknowledgements. This study was partially funded by the '100 Talents Program of the Chinese Academy of Sciences', China and 'Special Coordination Funds for Promoting Science and Technology' ‘Red Tide Watcher' of MEXT, Japan. Ship data of chl a were measured by Dr. D. Suchnt and Dr. W. Puntip (Department of Marine Science, Kasetsart University, Thailand) supported by the Interdepartmental Collaborative Research Program. QuikScat data were produced by Remote Sensing Systems and sponsored by the NASA Ocean Vector Winds Science Team. Dr. D. R. Kester and Dr. W. L. Woods of the Graduate School of Oceanography, University of Rhode Island, provided useful comments on the manuscript, which we greatly appreciate. We thank Dr. J. Y. Hu of Xiamen University for his assistance in preparing Fig. 8. This paper was presented at the 2nd Workshop on Material Transport in the Coastal Seas of Southeast Asia in January 2003 (Japan), and at the Workshop on Red Tide Monitoring in Asian Coastal Water in March 2003 (Tokyo, Japan).

\section{LITERATURE CITED}

Andersen OB (1995) Global ocean tides from ERS 1 and TOPEX/POSEIDON altimetry. J Geophys Res (C) 100: $25249-25259$

An NT, Du HT (2000) Studies on phytoplankton pigment: chlorophyll, total carotenoids and degradation products in Vietnamese waters (The South China Sea, Area IV). In: Southeast Asian Fisheries Development Center (ed) Proceedings of the SEAFDEC seminar on fishery resources in the South China Sea, area IV: Vietnamese water. Southeast Asian Fisheries Development Center, Bangkok, p 1-18
Baith K, Lindsay R, Fu G, McClain CR (2001) SeaDAS: data analysis system developed for ocean color satellite sensors. EOS 82:202

Emery WJ, Thomas AC, Collins MJ, Crawford WR, Mackas DL (1986) An objective method for computing advective surface velocities from sequential infrared satellite images. J Geophys Res 91 (C11):12 865-12 878

Fang W, Fang G, Shi P, Huang Q, Xei Q (2002) Seasonal structures of upper layer circulation in the southern South China Sea from in situ observation. J Geophys Res 107 (C11):3202-3212

Ho CR, Zheng Q, Soong YS, Kuo NJ, Ho JH (2000) Seasonal variability of sea surface height in the South China Sea observed with TOPE/POSEIDON altimeter data. J Geophys Res 105 (C6):13 981-13990

Hsu CH, Lee KT, Lee MA, Liao CH, Lu HJ (2000) Effects of seasonal environment changes on the mackerel purse seine fishery in the waters off northeast Taiwan monitored by satellite remote sensing. In: Taiwan Fish Res Inst (ed) Proceedings of the joint Taiwan-Australia aquaculture and fisheries resource and management forum. Taiwan Fishery Research Institute, Keelung, p 257-261

Hu J, Kawamura H, Hong H, Qi Y (2000) A review on the currents in the South China Sea: Seasonal circulation, South China Sea Warm Current and Kuroshio intrusion. J Oceanogr 56:607-624

Kishino M, Ishimaru T, Furuya K, Oishi T, Kawasaki K (1998) In-water algorithms for ADEOS/OCTS. J Geophys Res 54: 431-436

Kubota M (1994) A new cloud detection algorithm for nighttime AVHRR/HRPT data. J Geophys Res 50:31-41

Kuo NJ, Zheng QN, Ho CR (2000) Satellite observation of upwelling along the Western Cast of the South China Sea. Remote Sens Environ 74:465-470

Li HW, HO CR, Kuo NJ, Chen CT, Tsai WP (1999) A comparison of OCI and SeaWIFS satellite imagery in the water adjacent to Taiwan. Terrestrial, Atmospheric and Oceanic Sciences 10(4):873-883

O'Reilly JE, Maritorena S, Mitchell BG, Siegel DA, Carder KL, Garver SA, Kahru M, McClain C (1998) Ocean color chlorophyll algorithms for SeaWiFS. J Geophys Res (C) 103:24 937-24 953

Penjan R, Siriporn P, Natinee S, Somboon S (2000) Temperature, salinity, dissolved oxygen and water masses of Vietnam waters. In: Southeast Asian Fisheries Development Center (ed) Proceeding of the SEAFDEC seminar on fishery resources in the South China Sea, area IV: Vietnamese water. Southeast Asian Fisheries Development Center, Bangkok, p 346-355

Sathyendranath S, Bukata RP, Arnone R, Dowell MD and 5 others (2000) Colour of case 2 waters. In: Sathyendranath $\mathrm{S}$ (ed) Remote sensing of ocean color in coastal, and other optically-complex, water. International Ocean-Color Coordinating Group (IOCCG), Dartmouth, p 23-46

Shaw PT, Chao SY (1994). Surface circulation in the South China Sea. Deep Sea Res I 41:1663-1683

Suchint D, Puntip W (2000) Sub-thermoline chlorophyll maximum in the South China Sea. In: Southeast Asian Fisheries Development Center (ed) Proceeding of the SEAFDEC seminar on fishery resources in the South China Sea area IV: Vietnamese water. Southeast Asian Fisheries Development Center, Bangkok, TD/KU- (3) p 1-19

Tang DL, Kawamura H (2002) Ocean color monitoring of coastal environments in the Asian waters. J Korea Soc Oceanogr 37:154-159

Tang DL, Ni IH, Müller-Karger FE, Liu ZJ (1998) Analysis of annual and spatial patterns of CZCS-derived pigment 
concentrations on the continental shelf of China. Cont Shelf Res 18:1493-1515

Tang DL, Ni IH, Kester DR, Müller-Karger FE (1999) Remote sensing observation of winter phytoplankton blooms southwest of the Luzon Strait in the South China Sea. Mar Ecol Prog Ser 191:43-51

Tang DL, Kawamura H, Luis AJ (2002a) Short-term variability of phytoplankton blooms associated with a cold eddy on the northwestern Arabian Sea. Remote Sens Environ 81: 81-89

Tang DL, Kester DR, Ni IH, Kawamura H, Hong HS (2002b) Upwelling in the Taiwan Strait during the summer monsoon detected by satellite and shipboard measurements. Remote Sens Environ 83:456-471

Tang DL, Kawamura H, Guan L (2003a) Long time observation of Taiwan Strait upwelling in summer season. Adv Space Res 32 (in press)

Editorial responsibility: Otto Kinne (Editor),

Oldendorf/Luhe, Germany
Tang DL, Kawamura H, Lee MA, Dien VT (2003b) Seasonal and spatial distribution of chlorophyll $a$ and water conditions in the Gulf of Tonkin, South China Sea. Remote Sens Environ 85:475-483

Tang DL, Kester DR, Ni IH, Qi YZ, Kawamura H (2003c) In situ and satellite observations of a harmful algal bloom and water condition at the Pearl River estuary in late autumn 1998. Harmful Algae 2:89-99

Wentz FJ, Smith DK, Mears CA, Gentemann CL (2001) Advanced algorithms for QuikScat and SeaWinds/AMSR. In: Proc Int Geosciences Remote Sens Symp (IGARSS)'01 2001. NASA

Wyrtki K (1961) Physical oceanography of the Southeast Asian waters. Scientific results of marine investigations of the South China Sea and the Gulf of Thailand, NAGA Report 2, Scripps Institution of Oceanography, La Jolla, CA

Submitted: March 26, 2003; Accepted: November 18, 2003 Proofs received from author(s): February 17, 2004 